
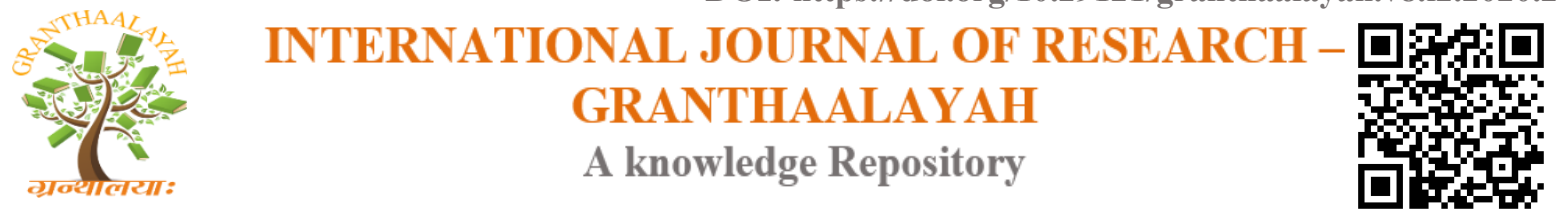

Social

\title{
COGNITIVE AND EMOTIVE ASPECTS OF LEARNING POPULATION EDUCATION AMONG STUDENTS IN CHENNAI
}

\author{
Dr. A. Pareet Jayadevi ${ }^{* 1}$ \\ ${ }^{*}$ Assistant Professor, MEASI College of Education, No.2, Demellows Road, Choolai, Chennai- \\ 600112, TamilaNadu, India
}

\begin{abstract}
The main purpose of educational programmes has to create the realization in every teacher in regarding the close relationship between education and social change for which a strong educational base is needed for any social revolution. Through population education teacher should try to form the correct attitudes in adolescents striding in schools and colleges, so that by the time they get into the reproductive stage they would be in a position to make their own decisions. Population Education is must in school education because young people all over the world have common needs in order to achieve full and healthy development; a positive and stable family life; an understanding about their bodies, including the emotional and physical capacities that enable them to have sexual relations and reproduce; an awareness of population issues and how these issues will affect them; and the knowledge and skills to deal with these matters responsibly, now and in the future. The present study assesses the cognitive and emotive aspects of population education among students and reveals attitude of the students towards population education.
\end{abstract}

Keywords: Population Education; Cognitive; Emotive; School; Learning; Attitude.

Cite This Article: Dr. A. Pareet Jayadevi. (2020). "COGNITIVE AND EMOTIVE ASPECTS OF LEARNING POPULATION EDUCATION AMONG STUDENTS IN CHENNAI." International Journal of Research - Granthaalayah, 8(2), 168-175.

\section{Introduction}

The tremendous rate of increasing population is the hectic socioeconomic problem of India. The awareness about the population should not only be extended among the adults but also to be created among the students, who are the pillars of future India. This awareness has to be given to them through the educational system itself. Nowadays majority of youth population is getting migrated and staying away from family for reasons like higher education, employment etc. Students must be educated at the right age about the implication of the population growth. It must be imprinted into their minds that to lead a happy and safety life. Education is the only means to change attitude of the individuals and help them to make rational decisions. Hence, this topic was selected to check the Cognitive and Emotive aspects of learning population Education among students. 


\section{Need for the study}

The results of the impact of a school-based HIV prevention intervention on students' knowledge, attitudes, and behavior related to HIV infection (July 1994), suggest that skills-based risk reduction programs can have an effect on student behavior. The school-based interventions can reduce behavior associated with risk of HIV infection. So, population education is required in schools and colleges. Looking towards the need of the population education for school and college going population the researcher has felt the need to work on the topic - "Cognitive and Emotive aspects of Learning Population Education among students". The researcher assesses the awareness and opinion about population education, attitudes towards the population education, beliefs about the population education, willingness to receive the population education and favorable conditions of educational environment for population education among school and college going students. Being a part of community, they might have some, religious, social, economic beliefs which have affected their thinking. So, in view of all the above facts, the researcher has considered studying the problem. Similarly, students of higher secondary stage are studying various subjects and getting knowledge of various important and useful areas of human life. How far that knowledge is related with their future family requirements? Are they familiar with the concept "happy family" on the basis of achieved knowledge? Has education succeeded to change their attitudes and beliefs from traditional way to the modern lifestyle? How educational institutions influenced students' thinking, behavior and beliefs in respect of family welfare? These are some points which prove the need of the study.

\section{Definitions of Terms Used in this Study}

- Population Education: The term 'population education' stands for a concept of teachinglearning process which works in the area of demography, family-welfare, its socioeconomic effects and discussions over the population problem at national and international level.

- Cognitive: Cognition is a term referring to the mental processes involved in gaining knowledge and comprehension. These processes include thinking, knowing, remembering, judging, problem-solving, awareness, opinion and beliefs. These are higher-level functions of the brain and encompass language, imagination, perception, and planning.

- Emotive: The definition of emotive is someone or something with the ability to express emotions. Emotive is used to mean attitude and willingness. Emotion is a complex of feelings, a general stirring up of the individual, physically and mentally a state of intensified excitement.

- School: School will be a place where moral education is provided not in the form of separate lessons and precepts but through activities performed jointly with others. The school must enable the child to be aware of himself and of the society (John Dewey).

- Learning: Learning as the process of acquisition of knowledge, habits and attitudes (Crow and Crow).

- Attitude: An attitude is a learned predisposition to respond in a favorable or unfavorable manner towards people, an object, an idea or a situation (Martin Fishbein) 


\section{Objectives of this Study}

The following objectives are attempted in this present study:

- To assess the level of awareness of higher secondary school students as well as college students of Chennai city about population education.

- To assess the level of opinion of higher secondary school students as well as college students of Chennai city about population education.

- To study the attitude of higher secondary school students as well as college students of Chennai city about population education.

- To study the beliefs (social, religious and economic) higher secondary school students as well as college students of Chennai city about population education.

- To estimate the willingness to learn population education of higher secondary school students as well as college students of Chennai city to receive about population education.

\section{Hypothesis for the Present Study}

- There is no significant difference between School and College Students with respect to dimension of Population Education.

- There is no significant difference in respect of population education among higher secondary school students and among sub samples like gender, religion, management type of institution, size of the family, Socio-Economic status and reading habit of newspaper.

- There is no significant difference in respect of population education among college students and among sub samples like gender, religion, management type of institution, size of the family, Socio-Economic status and reading habit of newspaper.

\section{Scope of the Study}

As the field of research in population education is broad, in order to confine the research, the scope of the study confined to the Higher Secondary and College students, because student population enters into fertility age group and sometimes in productivity age group also at this age.

\section{Research Approach}

This research study was carried out in well-planned manner and systematic effort. The investigation has adopted a definite procedure. After formulating the problem, the data has been collected through questionnaire survey. The research has been validated by statistical method and has been described under 5 sub-heads: 1. Population and Sample: Nature, Characteristics and Composition 2. Construction and Description of Research Instrument (Questionnaires) 3. Administration of the Questionnaires and Collection of Data 4. Scoring, Categorization and Analysis 5. Statistical Techniques and Data Interpretation

\subsection{Population and Sample}

The researcher has selected Higher Secondary School students and College Students as the population for this study. The sample was drawn from Colleges and School classes of XI and XII 
in Chennai City of Tamil Nadu. Totally 50 institutions were selected for the study on random basis which includes 20 Colleges and 30 Schools. 1000 students are selected for the study. Of which are College Students and are Higher Secondary School Students. Samples are selected to have a mix of both male and female students. Total sample includes 500 boys (50\%) and 500 girls (50\%).

\subsection{Development of the Research Tool}

The research tool was developed after studying various related literatures and on the basis of 6 dimensions (Mahesh Deouskar,1997) to study the Cognitive and Emotive aspects of Population Education. The dimension (dependent variables) such as, Awareness, Opinion, Attitude, Beliefs \& Willingness were assessed through Multiple choice questions, Likert method (Mahesh Deouskar,1997), Proactive Coping Inventory respectively. These may influence by independent variables such as gender, religion, management type, residential status, family size, socioeconomic status and the reading habit of newspaper. So assessing Awareness, opinion and beliefs will point out the cognitive level and assessing attitude and willingness shows the emotional aspect.

\subsection{Data Analysis}

The ' $t$ ' test of significance was used to determine the significance of difference between the Mean scores of Cognitive and Emotive aspects among School and College Students.

Hypothesis 1: There is no significant difference between School and College Students with respect to dimension of Population Education.

Table 1: Summary of Significance Difference Between School and College students

\begin{tabular}{|c|c|c|c|c|c|c|c|}
\hline \multirow{3}{*}{$\begin{array}{l}\text { Dimensions of } \\
\text { Population Education }\end{array}$} & \multicolumn{4}{|c|}{ Category of Students } & \multirow{3}{*}{ t value } & \multirow{3}{*}{$P$ value } & \multirow{3}{*}{ Remark } \\
\hline & \multicolumn{2}{|c|}{ School } & \multicolumn{2}{|c|}{ College } & & & \\
\hline & Mean & SD & Mean & SD & & & \\
\hline Awareness & 108.70 & 11.39 & 113.89 & 8.63 & 8.19 & $0.000^{* *}$ & Significant \\
\hline Opinion & 64.07 & 6.65 & 65.19 & 6.10 & 2.77 & $0.006^{* *}$ & Significant \\
\hline Attitude & 88.57 & 9.64 & 96.67 & 8.21 & 14.35 & $0.000^{* *}$ & Significant \\
\hline Belief & 35.38 & 4.16 & 37.57 & 3.24 & 9.35 & $0.000^{* *}$ & Significant \\
\hline Willingness & 34.59 & 4.32 & 37.59 & 2.42 & 13.83 & $0.000^{* *}$ & Significant \\
\hline Total & 331.31 & 21.37 & 350.91 & 16.04 & 16.55 & $0.000^{* *}$ & Significant \\
\hline
\end{tabular}

Note: $* *$ denotes significant at $1 \%$ level

Since $\mathrm{P}$ value is less than 0.001 , the null hypothesis is rejected at $1 \%$ level. Hence there is significant difference between School and College Students with respect to dimension of Population Education. 




Figure 1: Cognitive and Emotive aspects of Learning Population Education

The above picture shows that the significance difference in the mean Cognitive and Emotive aspects of Learning Population Education between school and college students.

Hypothesis 2: There is no significant difference in respect of population education among higher secondary school students and among sub samples like gender, religion, management type of institution, size of the family, Socio-Economic status and reading habit of newspaper.

Table 2: Summary of Significance Difference (School Students)

\begin{tabular}{|c|c|c|c|c|c|}
\hline \multicolumn{2}{|c|}{ Dimensions of Population Education } & \multicolumn{2}{|c|}{$\begin{array}{c}\text { Cognitive and } \\
\text { Emotive aspects }\end{array}$} & \multirow[t]{2}{*}{$\begin{array}{l}t \text { value } / \\
\text { F Value }\end{array}$} & \multirow[t]{2}{*}{ P Value } \\
\hline & & Mean & SD & & \\
\hline \multirow[t]{2}{*}{ Gender } & Boys & 327.56 & 16.58 & \multirow[t]{2}{*}{3.78} & \multirow[t]{2}{*}{$0.000^{* *}$} \\
\hline & Girls & 335.06 & 24.74 & & \\
\hline \multirow{4}{*}{ Religion } & Hindu & 339.15 & 21.67 & \multirow[t]{4}{*}{27.30} & \multirow[t]{4}{*}{$0.000 * *$} \\
\hline & Christian & 328.7 & 18.52 & & \\
\hline & Muslim & 326.29 & 18.85 & & \\
\hline & Others & 313.5 & 13.79 & & \\
\hline \multirow[t]{3}{*}{ Management Type } & Government & 346.62 & 23.24 & \multirow[t]{3}{*}{39.30} & \multirow[t]{3}{*}{$0.000 * *$} \\
\hline & $\begin{array}{l}\text { Government } \\
\text { Aided }\end{array}$ & 331.17 & 20.35 & & \\
\hline & Private & 320.03 & 16.59 & & \\
\hline \multirow[t]{2}{*}{ Residential Status } & Hostel & 324.24 & 17.25 & \multirow[b]{2}{*}{6.37} & \multirow[b]{2}{*}{$0.000 * *$} \\
\hline & Day Scholar & 344.24 & 24.06 & & \\
\hline \multirow[t]{2}{*}{ Family Size } & $\begin{array}{ll}\text { Below } & 3 \\
\text { Children }\end{array}$ & 327.75 & 19.90 & \multirow{2}{*}{3.61} & \multirow{2}{*}{$0.000 * *$} \\
\hline & 3 and above & 334.94 & 22.23 & & \\
\hline Socio- Economic Status & Low & 336.98 & 26.29 & & \\
\hline
\end{tabular}




\begin{tabular}{|l|l|l|l|l|l|}
\hline \multirow{2}{*}{ Reading Habit of Newspaper } & Average & 329.08 & 19.32 & \multirow{2}{*}{6.43} & $0.001^{* *}$ \\
\cline { 2 - 4 } & High & 329.04 & 17.56 & & \\
\cline { 2 - 4 } & Regular & 338.31 & 13.96 & \multirow{3}{*}{25.68} & \multirow{3}{*}{$0.000^{* *}$} \\
\cline { 2 - 4 } & Occasional & 336.01 & 23.69 & & \\
\cline { 2 - 4 } & Not reading & 322.49 & 17.52 & & \\
\hline
\end{tabular}

Note: $* *$ denotes significant at $1 \%$ level

This table shows that the girl students, students of Hindu religion, Government School students and students reading newspaper regularly of schools are having higher cognitive and emotive aspects of Population Education.

Hypothesis 3: There is no significant difference in respect of population education among college students and among sub samples like gender, religion, management type of institution, size of the family, Socio-Economic status and reading habit of newspaper.

Table 3: Summary of Significance Difference (College Students)

\begin{tabular}{|c|c|c|c|c|c|}
\hline \multirow{2}{*}{\multicolumn{2}{|c|}{ Dimensions of Population Education }} & \multicolumn{2}{|c|}{$\begin{array}{c}\text { Cognitive and } \\
\text { Emotive aspects }\end{array}$} & \multirow[t]{2}{*}{$\begin{array}{l}\text { t value / } \\
\text { F Value }\end{array}$} & \multirow[t]{2}{*}{ P Value } \\
\hline & & Mean & SD & & \\
\hline \multirow[t]{2}{*}{ Gender } & Boys & 347.61 & 16.39 & \multirow[t]{2}{*}{4.93} & \multirow[b]{2}{*}{$0.000 * *$} \\
\hline & Girls & 354.21 & 14.99 & & \\
\hline \multirow[t]{4}{*}{ Religion } & Hindu & 352.94 & 16.78 & \multirow[t]{4}{*}{7.85} & \multirow{4}{*}{$0.000 * *$} \\
\hline & Christian & 352.46 & 16.47 & & \\
\hline & Muslim & 345.71 & 13.03 & & \\
\hline & Others & 357.00 & 10.61 & & \\
\hline \multirow[t]{3}{*}{ Management Type } & Government & 357.47 & 14.30 & \multirow[t]{3}{*}{46.10} & \multirow[t]{3}{*}{$0.000 * *$} \\
\hline & $\begin{array}{l}\text { Government } \\
\text { Aided }\end{array}$ & 354.89 & 13.97 & & \\
\hline & Private & 344.32 & 15.61 & & \\
\hline \multirow{2}{*}{ Residential Status } & Hostel & 349.26 & 1594 & \multirow[t]{2}{*}{2.95} & \multirow[t]{2}{*}{$0.003 * *$} \\
\hline & Day Scholar & 353.34 & 15.90 & & \\
\hline \multirow[t]{2}{*}{ Family Size } & Below 3 & 354.94 & 14.81 & \multirow[t]{2}{*}{5.17} & \multirow[t]{2}{*}{$0.000 * *$} \\
\hline & 3 and above & 347.95 & 16.28 & & \\
\hline \multirow[t]{3}{*}{ Socio- Economic Status } & Low & 353.61 & 16.10 & \multirow[t]{3}{*}{5.35} & \multirow[t]{3}{*}{$0.005^{* *}$} \\
\hline & Average & 348.46 & 16.02 & & \\
\hline & High & 352.19 & 15.46 & & \\
\hline \multirow[t]{3}{*}{ Reading Habit of Newspaper } & Regular & 350.37 & 16.83 & \multirow[t]{3}{*}{2.61} & \multirow[t]{3}{*}{0.074} \\
\hline & Occasional & 362.00 & 15.06 & & \\
\hline & Not reading & 350.16 & 5.98 & & \\
\hline
\end{tabular}

Note: $* *$ denotes significant at $1 \%$ level

This table shows that the cognitive and emotive aspects of Population Education among the college students is more or less equal irrespective of various independent variables naming Gender, Religion, Management type of schools, Socio-Economics status and reading habit of newspaper. 


\section{Finding of this Study}

The college students possess strong belief and attitude towards Population Education. The Female students are more aware and having sound understanding than the male students. This reveals the positive cognitive and emotive aspects of girl students towards learning Population Education.

\section{Conclusion}

The findings of the research strongly favourable to the need for Population Education among the students to inculcate the Cognitive and Emotive aspects of learning Population Education among both School and College Students. Even though they have favourable attitude towards attending and listening to the lectures on Population Education, they need more awareness about child abuse and sexual abuse which are affected the Indian society. Through Population Education they can learn to sex education, they can be trained self-resistance and utilized human resources in proper.

\section{Educational Implications}

The students of fertility age-group as well as of reproductive age-group need to be motivated through Population Education by the activities such as organizing film shows, exhibitions, essay competitions, elocution contests and awareness programme on population, environment, AIDS and the like should be arranged. They may useful to lead healthy and safety life for student's future.

\section{Suggestions}

The present study suggested to the future social and educational scientists must prompt and promote research in the area of Population Education and should facilitate Service-Learning Scheme for widespread dissemination of population education. The educational institutions may get help from Women Self Help Groups / Mahalir Suya uthavi Kuzhu to disseminate information small family norms to the students elsewhere students can organize population club activities and creating awareness through Red Ribbon Club and involve in census related works.

\section{References}

[1] Balaji M, Andrews T, Andrew G, Patel V. The acceptability, feasibility, and effectiveness of a population-based intervention to promote youth health: an exploratory study in Goa, India. The Journal of adolescent health: official publication of the Society for Adolescent Medicine. 2011;48(5):453-60.

[2] International Institute of Population Sciences. National Family Health Survey- 4. India: International Institute of Population Sciences, 2015-16

[3] Jayne, Susan H., Guilkey, and David K. Contraceptive determinants in three leading countries, Population Research and Policy Review, August, Vol. 17, 1998, 329-350

[4] Magnani R. J. The effects of monetized food aid on reproductive behavior in rural Honduras, Population Research and Policy Review, August, Vol. 17, 1998, 305-328.

[5] Meekers. D. Pregnancy-related school dropouts in Botswana, Population Studies, March, Vol. 53, 1999, 195-209

[6] Registrar General \& Census Commissioner of India. Census of India New Delhi 2011, from: http://www.censusindia.gov.in 
[7] UNESCO - Educational statistics 2004: Regional report on South and East Asia. Retrieved December 19, 2004, from http://www.unesco.org/

[8] U.K., Prime Minister. Teenage Pregnancy Rates 'Too High', Press Association News file, 2008.

*Corresponding author.

E-mail address: apjdevi@ gmail.com 